\title{
Measurement of Study Productivity and Evaluation Analysis by using the American Productivity Center (APC) Model at a Palm Oil Factory (Pks PT. Syaukath Sejahtera)
}

Measurement of Study Productivity and Evaluation

\author{
Bakhtiar and Defi Irwansyah \\ Industrial Engineering of Department, Malikussaleh University, Lhokseumawe, \\ Indonesia \\ Zulmiardi \\ Mechanical Engineering of Department, Malikussaleh University, Lhokseumawe, \\ Indonesia
}

\begin{abstract}
Purpose - This study aims to determine the results of productivity index, profitability and improvement of company prices and to understand the relationship between partial input factors and productivity, profitability, and price fixing.

Design/Methodology/Approach - In this work, the productivity at the palm oil factory PT Sayaukath Sejahtera was measured and evaluated by using The American Productivity Center (APC) model approach.

Findings/Results - The results showed that each index that has been analyzed has a $5.143 \%$ decrease in the productivity index per year with a profitability equal to $0.286 \%$ per year and an increase in the price improvement index of $5.143 \%$ per year. Thus, it is concluded that from each index that has been analyzed, there is a decrease in the productivity index and profitability per year and there is an annual increase in the price improvement index.
\end{abstract}

Research Limitations/Implications (if applicable) -

Practical Implications (if applicable) -

Originality/Value -

Keywords Recapitulation of productivity index, profitability, price improvement

All papers within this proceedings volume have been peer reviewed by the scientific committee of the Malikussaleh International Conference on Multidisciplinary Studies (MICoMS 2017).

(C) Bakhtiar, Defi Irwansyah, Zulmiardi. Published in the Emerald Reach Proceedings Series. Published by Emerald Publishing Limited. This article is published under the Creative Commons Attribution (CC BY 4.0) licence. Anyone may reproduce, distribute, translate and create derivative works of this article (for both commercial and non-commercial purposes), subject to full attribution to the original publication and authors. The full terms of this licence may be seen at http:// creativecommons.org/licences/by/4.0/legalcode

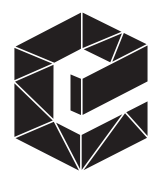




\section{Proceedings of 1. Introduction}

MICoMS 2017 Productivity is defined as the relationship between the input and the output of a production system. This relationship is commonly expressed as the ratio of output divided by input. If more output is produced with the same input, then it is termed as an increase in productivity. Likewise, if lower input can produce the same output, then the productivity is likely to increase.

82

Productivity is also defined as the level of efficiency in producing goods or services. Productivity gives an idea as to how to utilize resources in producing goods. Productivity holds the key in identifying the valuable outputs and inputs, such as the efficiency and effectiveness of available resources, namely personnel, machinery, materials, capital, facilities, energy, and time to reach a very valuable output.

\section{Methods}

\subsection{Place and Object}

To gather the data for this study, a direct research was done on objects at the PT. Syaukath Sejahtera that is located in the KeudeLapang village, Ganda Pura district, Bireuen, Nanggro Aceh Darusalam. The data used for the analysis are obtained by collecting the primary data from interviews. Observation and secondary data were used according to the needs of data analysis.

\section{Results and discussion}

\subsection{Calculation of the Productivity Index}

This section provides details on the calculation of the input index and partial productivity of labor for the period 3-8 (2009-2014). Table 1 shows the recapitulation of the results of the calculation of the partial input productivity index.

\subsection{Calculation of the Total Factor Productivity}

This section shows the calculation of the total factor productivity index for the period 3-8 (2010-2015). Table 2 shows the results of the calculation of the recapitulation of the total factor productivity index.

\begin{tabular}{lrrrrr}
\hline Year & Labor & Material & Energy & Capital & Maintenance \\
\hline 2010 & 100 & 100 & 100 & 100 & 100 \\
2011 & 72 & 53 & 90 & 101 & 54 \\
2012 & 88 & 77 & 103 & 100 & 60 \\
2013 & 123 & 107 & 124 & 98 & 60 \\
2014 & 103 & 90 & 88 & 98 & 67 \\
2015 & 80 & 70 & 67 & 96 & 74 \\
\hline
\end{tabular}

Table 1.

Partial Productivity

Index Score

\begin{tabular}{lccccr}
\hline Year & $\begin{array}{c}\text { Output } \\
(\text { Rp. })\end{array}$ & $\begin{array}{c}\text { Labor } \\
\left(\text { Rp. } \times 10^{3}\right)\end{array}$ & $\begin{array}{c}\text { Capital } \\
\left(\text { Rp. } \times 10^{3}\right)\end{array}$ & $\begin{array}{c}\text { Total Factor } \\
\text { Productivity Ratio }\end{array}$ & Index \\
\hline 2007 & $119,304,756.150$ & 136.800 & $50,000.000$ & 1.02 & 100 \\
2008 & $121,765,719.000$ & 192.000 & $70,000.000$ & 1.02 & 100 \\
2009 & $154,894,993,800$ & 201.600 & $90,000.000$ & 1.02 & 100 \\
2010 & $227,153,851,500$ & 211.200 & $111,000.000$ & 1.02 & 100 \\
2011 & $198,957,725.500$ & 220.800 & $130,000.000$ & 1.02 & 100 \\
2012 & $161,822,539.500$ & 230.400 & $150,000.000$ & 1.02 & 100 \\
\hline
\end{tabular}




\subsection{Total Productivity Calculations by Using American Productivity Center Model}

3.3.1. Calculation of the Output Index with Constant Prices The calculation of the output index for the period 3-8 (2010-2015) is done as discussed earlier. The results of the calculation can be seen in Table 3 .

3.3.2. Calculation of the Input Index with Constant Prices This section shows the calculation of the input index for the period 3-8 (2010-2015). The results of the calculation can be seen in Table 4 .

3.3.3. Calculation of the Productivity Index from 2010 to 2015 This section shows the calculation of the labor productivity index for the period 3-8 (2010-2015). The calculation results can be seen in Table 5 .

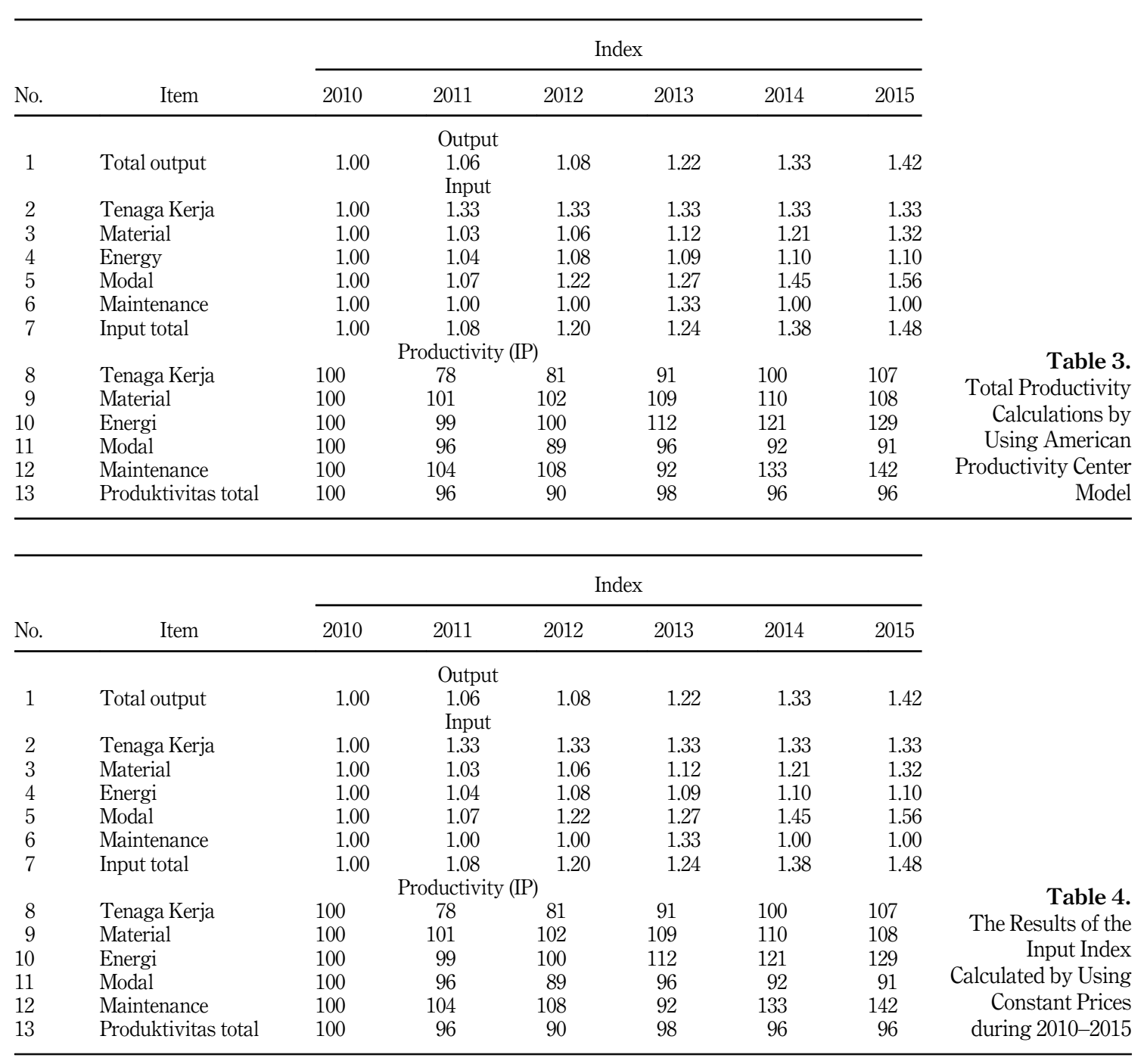

Measurement of Study Productivity and Evaluation 83 


\begin{tabular}{|c|c|c|c|c|c|c|c|c|}
\hline \multirow{3}{*}{$\begin{array}{l}\text { Proceedings of } \\
\text { MICoMS } 2017\end{array}$} & \multirow[b]{2}{*}{ No. } & \multirow[b]{2}{*}{ Item } & \multicolumn{6}{|c|}{ Index } \\
\hline & & & 2010 & 2011 & 2012 & 2013 & 2014 & 2015 \\
\hline & 1 & Total output & 1.00 & $\begin{array}{l}\text { Outpl } \\
1.06 \\
\text { Inpu }\end{array}$ & 1.08 & 1.22 & 1.33 & 1.42 \\
\hline \multirow{9}{*}{84} & 2 & Tenaga Kerja & 1.00 & 1.33 & 1.33 & 1.33 & 1.33 & 1.33 \\
\hline & 3 & Material & 1.00 & 1.03 & 1.06 & 1.12 & 1.21 & 1.32 \\
\hline & 4 & Energi & 1.00 & 1.04 & 1.08 & 1.09 & 1.10 & 1.10 \\
\hline & 5 & Modal & 1.00 & 1.07 & 1.22 & 1.27 & 1.45 & 1.56 \\
\hline & 6 & Maintenance & 1.00 & 1.00 & 1.00 & 1.33 & 1.00 & 1.00 \\
\hline & 7 & Input total & 1.00 & 1.08 & 1.20 & 1.24 & 1.38 & 1.48 \\
\hline & & \multicolumn{7}{|c|}{ Productivity (IP) } \\
\hline & 8 & Tenaga Kerja & 100 & 78 & 81 & 91 & 100 & 107 \\
\hline & 9 & Material & 100 & 101 & 102 & 109 & 110 & 108 \\
\hline Table 5. & 10 & Energi & 100 & 99 & 100 & 112 & 121 & 129 \\
\hline Calculation of the & 11 & Modal & 100 & 96 & 89 & 96 & 92 & 91 \\
\hline Productivity Index & 12 & Maintenance & 100 & 104 & 108 & 92 & 133 & 142 \\
\hline from 2010 to 2015 & 13 & Produktivitas total & 100 & 96 & 90 & 98 & 96 & 96 \\
\hline
\end{tabular}

3.3.4. Profitability Index Calculation This section shows the calculation of the output and input index for the period 3-8 (2010-2015). Recapitulation of these calculations can be seen in Tables 6-9.

3.3.5. Multiple Linear Regression Analysis Based on Table 10, it can be noted that without an enhancement in partial productivity the productivity index will decrease by 6.660. Any increase in the capital input productivity index used in conducting production activities by $1 \%$ will increase the total productivity index by $0.882 \%$. The capital input productivity has a large and significant coefficient value that occupies the most dominant position in its role of increasing total productivity.

\begin{tabular}{|c|c|c|c|c|c|c|c|}
\hline \multirow[b]{2}{*}{ No. } & \multirow[b]{2}{*}{ Item } & \multicolumn{6}{|c|}{ Index } \\
\hline & & 2010 & 2011 & 2012 & 2013 & 2014 & 2015 \\
\hline 1 & Total output & 1.00 & $\begin{array}{c}\text { Outpu } \\
1.15 \\
\text { Input }\end{array}$ & 1.32 & 1.61 & 1.89 & 2.18 \\
\hline 2 & Tenaga Kerja & 1.00 & 1.40 & 1.47 & 1.54 & 1.61 & 1.68 \\
\hline 3 & Material & 1.00 & 1.13 & 1.28 & 1.46 & 1.72 & 2.01 \\
\hline 4 & Energi & 1.00 & 1.13 & 1.25 & 1.52 & 1.88 & 2.02 \\
\hline 5 & Modal & 1.00 & 1.14 & 1.32 & 1.65 & 1.94 & 2.26 \\
\hline 6 & Maintenance & 1.00 & 2.12 & 2.18 & 2.68 & 2.83 & 2.93 \\
\hline 7 & Input total & 1.00 & 1.15 & 1.32 & 1.61 & 1.90 & 2.19 \\
\hline \multicolumn{8}{|c|}{ Productivity (IP) } \\
\hline 8 & Tenaga Kerja & 100 & 1.23 & 90 & 105 & 117 & 130 \\
\hline 9 & Material & 100 & 102 & 103 & 110 & 110 & 108 \\
\hline 10 & Energi & 100 & 102 & 106 & 106 & 101 & 108 \\
\hline 11 & Modal & 100 & 101 & 100 & 98 & 97 & 96 \\
\hline 12 & Maintenance & 100 & 54 & 61 & 60 & 67 & 74 \\
\hline 13 & Produktivitas total & 100 & 100 & 100 & 100 & 99 & 100 \\
\hline
\end{tabular}




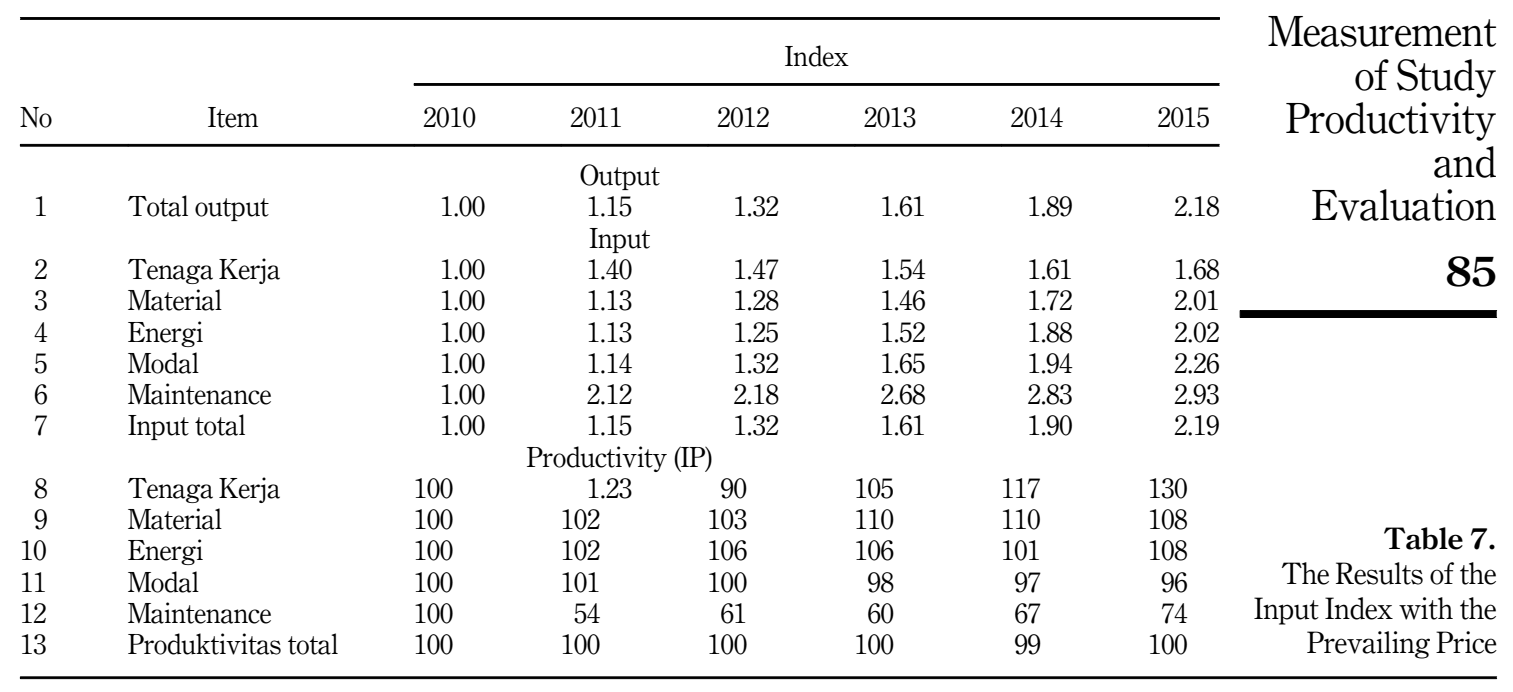

\begin{tabular}{|c|c|c|c|c|c|c|c|c|}
\hline \multirow[b]{2}{*}{ No. } & \multirow[b]{2}{*}{ Item } & \multicolumn{6}{|c|}{ Price Enhancement Index Rate } & \\
\hline & & 2010 & 2011 & 2012 & 2013 & 2014 & 2015 & \\
\hline & & \multicolumn{6}{|c|}{ Input } & \\
\hline 1 & Tenaga Kerja & 1.00 & 1.40 & 1.47 & 1.54 & 1.61 & 1.68 & \\
\hline 2 & Material & 1.00 & 1.13 & 1.28 & 1.46 & 1.72 & 2.01 & \\
\hline 3 & Energi & 1.00 & 1.13 & 1.25 & 1.52 & 1.88 & 2.02 & Table 8. \\
\hline 4 & Modal & 1.00 & 1.14 & 1.32 & 1.65 & 1.94 & 2.26 & Results of the Price \\
\hline 5 & Maintenance & 1.00 & 2.12 & 2.18 & 2.68 & 2.83 & 2.93 & Enhancement Index \\
\hline 6 & Input Total & 1.00 & 1.15 & 1.32 & 1.61 & 1.90 & 2.19 & 2010-2015 \\
\hline
\end{tabular}

By increasing the partial profitability, the total profitability index will decrease by 301.246. Any increase in the profitability index of capital inputs used in conducting production activities by $1 \%$ will increase the total profitability index by $3.226 \%$. The profitability of the capital input has a large and significant coefficient value that occupies the most dominant position in its role of increasing total profitability.

\begin{tabular}{lccc}
\hline Year & Profitability Index & Productivity Index & Price Enhancement Index \\
\hline 2007 & 100 & 100 & 100 \\
2008 & 100 & 96 & 104 \\
2009 & 100 & 90 & 111 \\
2010 & 100 & 98 & 102 \\
2011 & 99 & 96 & 103 \\
2012 & 100 & 96 & 104 \\
2013 & 100 & 97 & 103 \\
2014 & 99 & 91 & 109 \\
\hline
\end{tabular}

Table 9.

Recapitulation of the

Productivity,

Profitability, and Price Enhancement Index 
Proceedings of Increased partial price enhancement means the index of the total price enhancement will MICoMS 2017 decrease by 6.586. Any increase in the capital input price enhancement index, which in this case is defined as a product price of $1 \%$, will increase the index of the total price enhancement by $0.805 \%$. Enhancement in the capital input price has a large and significant coefficient value that occupies the most dominant position in its role of improving the total price enhancement.

\section{6}

\section{Conclusion}

Following the above discussion on partial productivity measurement analysis, total factor, and total productivity by using the American Productivity Center (APC) method, and by understanding the influence partial productivity has on the productivity, profitability, and price improvement by using multiple linear regression analysis, it can be concluded that from each index that has been analyzed, there is a decrease in the productivity index of $5.143 \%$ per year and profitability of $0.286 \%$ per year; there was an increase in the price improvement index of $5.143 \%$ per year. The most significant partial productivity factor in the total productivity is the partial productivity of capital inputs. It can be concluded that the partial capital input has a large coefficient value and is significant for the total productivity. The most influential factor for the input price improvement, i.e., the increase of the total price is the improvement of capital input prices. This can be interpreted in such a way that the partial capital input has a large and significant coefficient value to the total price increase.

\section{References}

Nasution, A.H. (2005). Industrial Management. Andi Offset, Yogyakarta.

Sinungan, M. (2008). Productivity-What And How. Earth Script, Jakarta.

Timpe, A.D. (1984). Productivity Analysis. Gramedia Pustaka Umum, Jakarta.

\section{Corresponding author}

Bahktiar can be contacted at bakti66@yahoo.com 